\title{
Tourism Related Perspectives of India Post Regarding the Post Offices Located in the Tourism Hotspots in NW India
}

Rohit Kanda ${ }^{1}$, Ghazali Bin Musa $^{2}$, Chef Sangeeta Dhar ${ }^{3}$, G. S. Bhalla ${ }^{1}$, Jasveen Kaur ${ }^{4}$, Nimisha Sharma $^{5}$, Koteswaran Dhandapani ${ }^{6}$, and S Gurusamy ${ }^{7}$

${ }^{1}$ School of Financial Studies, Guru Nanak Dev University, Amritsar, Punjab, India; ${ }^{2}$ Dept. of Business Policy and Strategy, University of Malaya, Kuala Lumpur, Malaysia; ${ }^{3}$ Dept. of Hotel and Hospitality Management, Pacific Institute of Hotel Management, Rajasthan, India; ' Dept. of Management Studies, Guru Nanak Dev University, Punjab, India; ${ }^{4}$ University Business School, Guru Nanak Dev University, Punjab India; ${ }^{5}$ Dept. of Tourism and Hospitality, I.K. Gujral Punjab Technological University, Amritsar, Punjab, India; ${ }^{6}$ School of Management, Vel Tech Rangarajan Dr. Sagunthala R\&D Institute of Science and Technology, Tamilnadu, India; ${ }^{7}$ School of Business Management, University of Madras, Chennai, Tamilnadu, India.

*Correspondence: rohitkanda.gndu@gmail.com (Dr. Rohit Kanda, UGC Funded Research Fellow (Commerce), School of Financial Studies, Faculty of Economics and Business, Guru Nanak Dev University, Amritsar, India).

\begin{abstract}
In the paper, we have revisited various locations, especially north-western India for the post offices settled in the key tourist spots/cities, as a point of interest, towards the tourism-related perspectives of India Post. The study is explorative in nature, being the first of its kind and sort. We have focused upon discussing such role of post offices on case to case basis. A purview of culture and tourism scenario is otherwise given in general. Postal Services network provides very important amenities at all the places. At many places, as indicated above, it helps in enhancing the tourism-related prospects of locality, and sometimes is a key component of tourism at a place. It has an important place in Indian heritage, culture, and tourism prospects.
\end{abstract}

Keywords: Tourism, India post, Post office, Tourism hotspots, Perspective, and North-Western India.

\section{INTRODUCTION:}

For around one hundred and fifty years, the Department of Posts (DoP) is the backbone of the country's communication and has been crucial in social economic development. Union Telecom Minister Ravi Shankar Prasad thanked India Post Office for extending a helping hand to the people in the hour of need. [India Post, 2020] Post Offices are making special efforts to serve far-flung areas of $\mathrm{J}-\mathrm{K}$, Ladakh and Himachal Pradesh.

Tourism in Delhi NCT - New Delhi (/'deli/, (Wells, 2008; Roach, 2011) Hindi: ('noi 'dil:i) (Naī Dillī) is an urban district. According to the 2011 census, Delhi's city proper population was over 11 million, the second-highest post Mumbai, (Scroll.in) an area now called National Capital Region. United Nations, (2016) Delhi ranks fifth in India in human development index. (Global Data Lab) Delhi has the second-highest GDP per capita in India. (Planning Department, Government of Delhi) Delhi has been continuously inhabited since more than a millennium. Asher, (2000) Jama Masjid - India's largest mosque [terragalleria.com] was built in 1656 [knowindia.gov.in] A variety of international cuisines are popular among the residents. Swamy, (2006) Housing the national capital, holding all of the best facilities, are being rushed upon by people from India and abroad, giving birth to variant streaks of tourism, alike medical tourism, religious tourism, and so on (Fig $\mathbf{1}$ and Fig 2). 


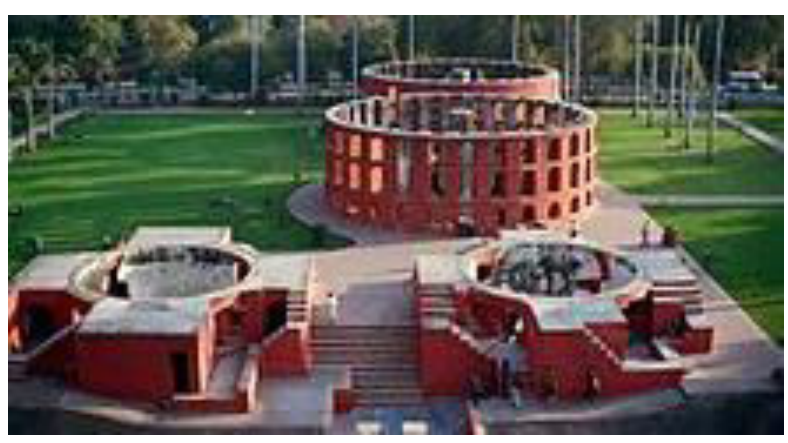

Fig 1: Jantar Mantar, New Delhi.

\section{Role of India Post}

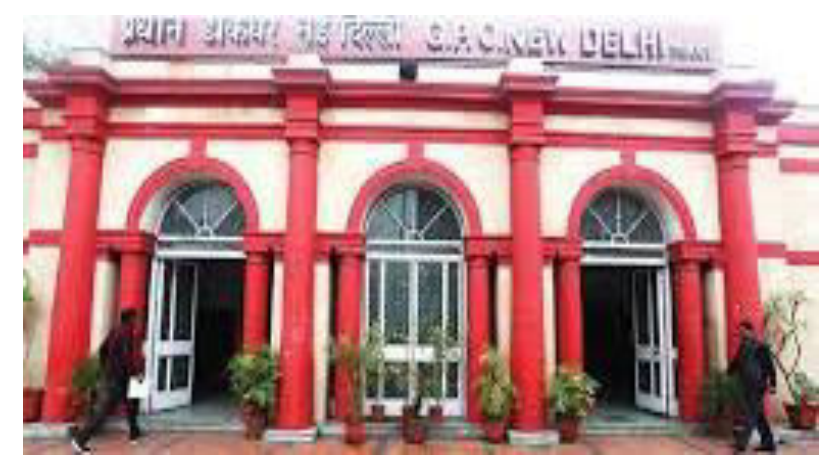

Fig 3: Gol Dak Khana, New Delhi HO.

Settled just opposite the holy Gurdwara Bangla Sahib, in the globally infamous Connaught Circus, Gol Dak Khana has much reverence and contribution to the development and modernisation, facilitating the communication (Fig 3). Same way, the Old Delhi Kashmiri Gate Head Post Office in facilitating the vicinity growth and strengthening the culturally and historically cultivated locality, having imprints of various dynasties (Fig 4).

National Philatelic Museum, New Delhi - At Dak Bhawan, it displays a number of frames in which exhibits of Post Independence era stamps can impress any Visitor with its charm, figured on the list of HOHO Bus prominent stops. [Delhi Tourism] Hence, the place adds much to the cultural and tourism reverence of the city in multifaceted etiquette (Sardar et al., 2020; Hossain et al., 2020).

Himachal Pradesh - The Government consist of Governor Bandaru Dattatreya (Reddy, 2019), Chief Justice Lingappa Narayana Swamy (IANS, 2019), Chief Minister Jai Ram Thakur (BJP). Legislature is Unicameral. (Hpvidhansabha.nic.in) Area in Total is $55,673 \mathrm{~km} 2$, with Area rank $18^{\text {th }}$ (indianmirror.com) among states of india. (Population 2011, Census of India 2011) in Total was $6,864,602$, Ranked $21^{\text {st }}$, having a Density of $123 / \mathrm{km} 2$. Language spoken officially is Hindi (Commissioner for Linguistic UniversePG I www.universepg.com

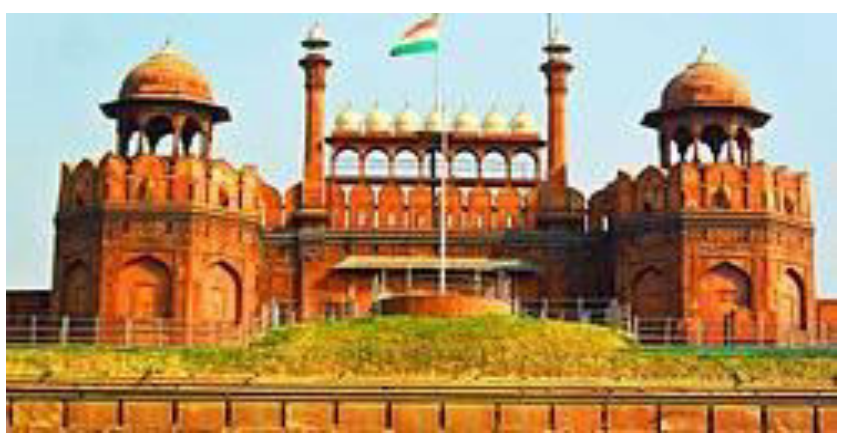

Fig 2: The Red Fort ('Lal Qilla').

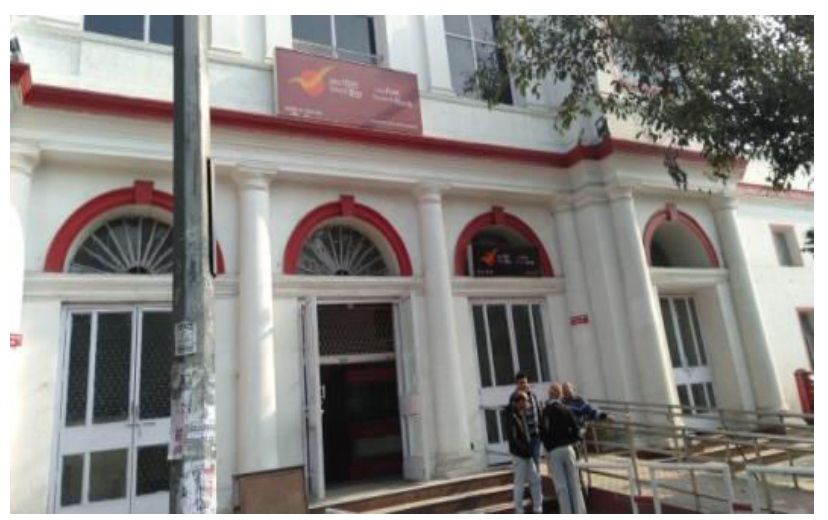

Fig 4: Old Delhi Kashmere Gate HO.

Minorities, Ministry of Minority Affairs, Government of India), with Additional official language Sanskrit (Chauhan, 2019; HDI, 2018) was 0.725 (Global Data Lab) (High), ranked 8th with Literacy of $83.78 \%$ (Government of India). The predominantly mountainous region comprising the presentday Himachal Pradesh has witnessed multiple waves of human migration from other areas, (Panchayati Raj Department, Government of Himachal Pradesh) declared open-defecation-free state in 2016.(Sharma, 2016) Survey of CMS India Corruption Study 2017 states Himachal Pradesh as India's least corrupt state.(The Times of India, 2017; Zee News, 2017)

Tourism \& Culture: The Himalayas attracts tourists from all over the world. Kullu Dussehra is nationally known. (Himachal Tourism) Lentils, rice, vegetables and chapati are staple (NDTV Food, 2016).

Role of India Post - Shimla is located on the steep hills of Jaakhoo, Mashobra, among others. In a remote setup India Post facilitates the smooth business of the Place. Settled on The Mall, Shimla Head Post Office, along with Shimla Postal Division $\mathrm{HQ}$, It adds a lot to the cultural and tourism value (Fig 5 and Fig 6). 


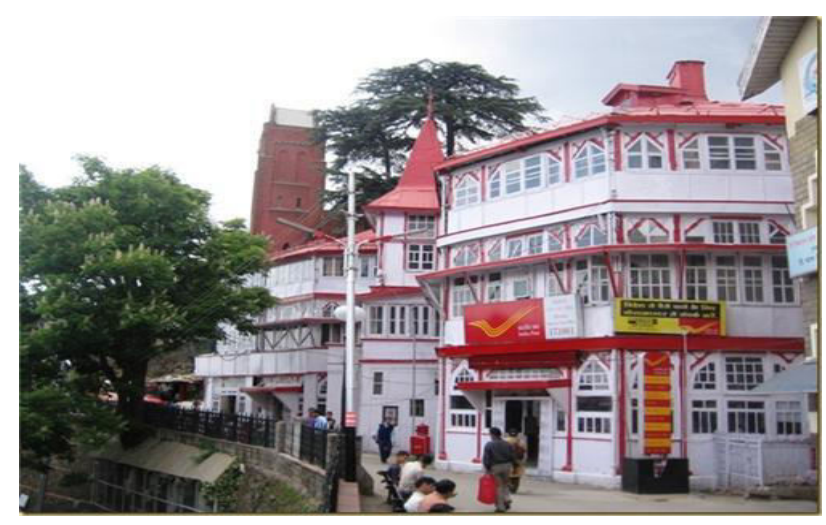

Fig 5: Shimla (H.P.)

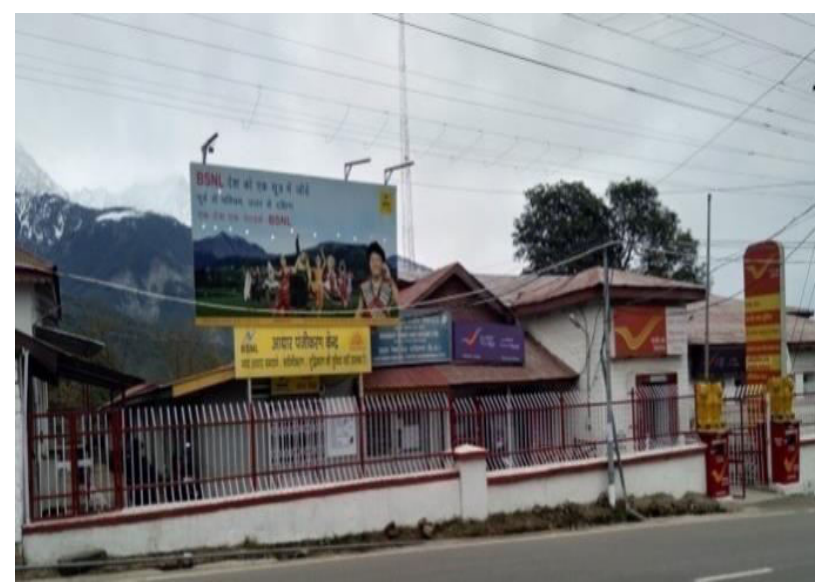

Fig 7: Dharamsala (H.P.)

The Head Post Office at Dharamsala has many stories to tell, being just settled on the entry point of the city, attracting many towards its vicinity adding to the blend of beauty of the premise. Kangra has much to say as an end stop of the Kangra valley narrow gauge railway line or having a stay place of infamous Brajeshwari Dham. The Head Post Office facilitate many tourist transact for their different needs in the journey. Additionally, India Post also facilitates for the parcel delivery at the doorstep for the tourist purchase made at the shopping outlets, especially for its MOU with HP Government ventures (Fig $\mathbf{7}$ and Fig 8).

Punjab, India - Punjab has Capital in Chandigarh, Largest city as Ludhiana and centre of religion in Amritsar, the Golden Temple. (Population, 2011) (censusindia.gov.in) was in Total 27,743,338, Ranked 16th, Density of 550/km2. GDP (2018-19) (Ministry of Statistics and Programme Implementation, Government of India; esopb.gov.in) in Total was 5.18 lakh crore. HDI (2018) was 0.723 (Global Data Lab), ranked 9th with Literacy (2011) of $76.68 \%$, with Punjabi as official language (Commissioner for Linguistic Minorities, Ministry of Mino-

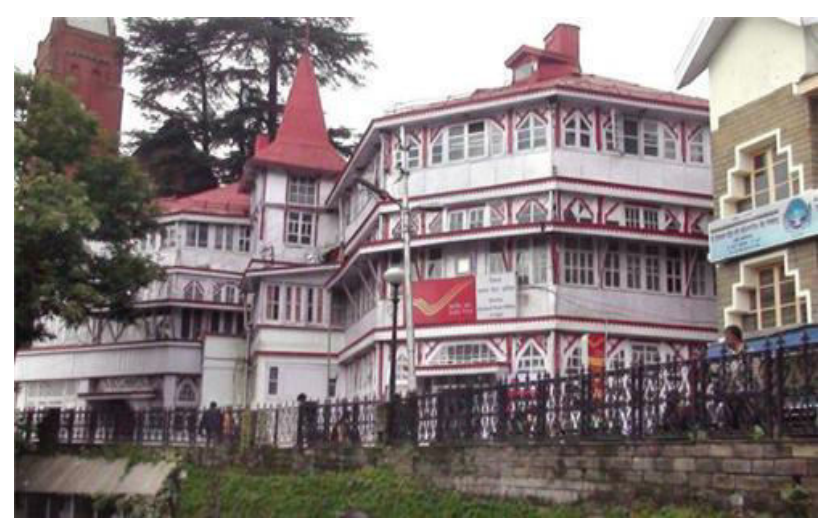

Fig 6: Shimla (H.P.)

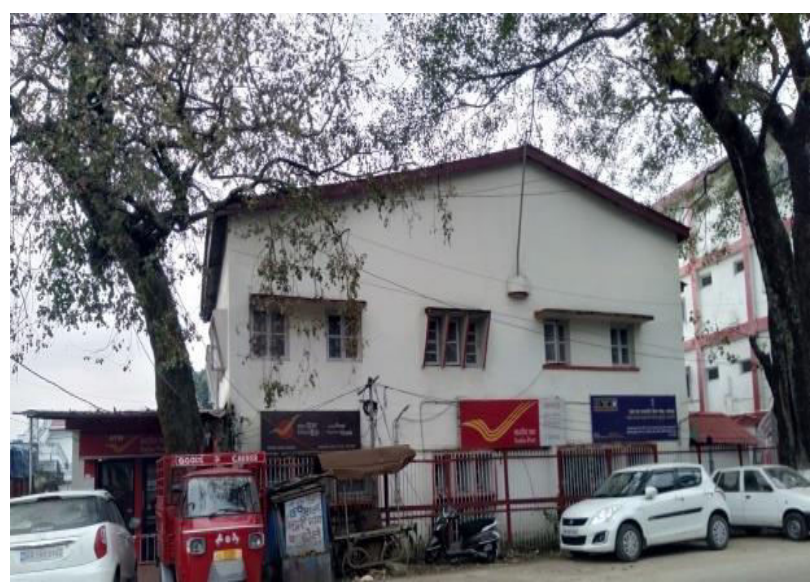

Fig 8: Kangra (H.P.)

rity Affairs, Government of India). The first traces of human habitation in India were found in the Punjab region. (Singh, 1988) The economy of Punjab is the 14th-largest, at 5.18 lakh crore GDP, a per capita GDP of 153,000. (Ministry of Statistics and Programme Implementation, Government of India; esopb. gov.in) Punjab has the ninth highest ranking among Indian states and union territories in human development index as of 2018. (Global Data Lab) Punjab is primarily agriculture-based with presence of abundant water sources and fertile soils. (Overseas Indian Facilitation Centre)

Tourism: Golden Temple, Durgiana Mandir and Devi Talab Mandir are holy places located in Punjab. (Dainik Bhaskar, 2015) World's first museum based on the Indian Partition of 1947, called the Partition Museum is in Amritsar. (Hindustan Times, 2019) Bhangra music has been infamous throughout the world. (The Times of India, 2014; Diwali, SikhNet) (Ilford Recorder) Mela Maghi, (Indian Express) Hola Mohalla, (IB Times, 2015) (India Today) Raksha Bandhan (Rakhri), Vaisakhi, Lohri etc. are events of attraction. 


\section{Role of India Post}

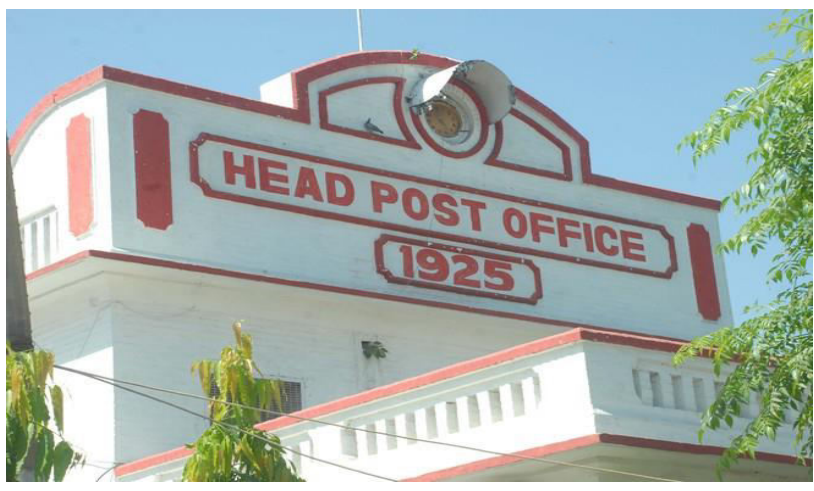

Fig 9: Amritsar (Punjab) .

Amritsar is religiously popular for infamous Golden Temple, Jallianwala Bagh, Indo-Pak Border Retreat Ceremony and many more. The Head Post Office at the Court Road, near rialto square is a popular place with many amenities for the tourist coming to the town. The historic building adds to the glory and historical significance of the place, with its indosarsenic artefact structures, adding to the tourism value and image of the city. In addition, the Golden Temple Post Office also adds on. Ludhiana, a transit station and hosiery industries hub, has its $\mathrm{HO}$ settled

\section{Role of India Post}

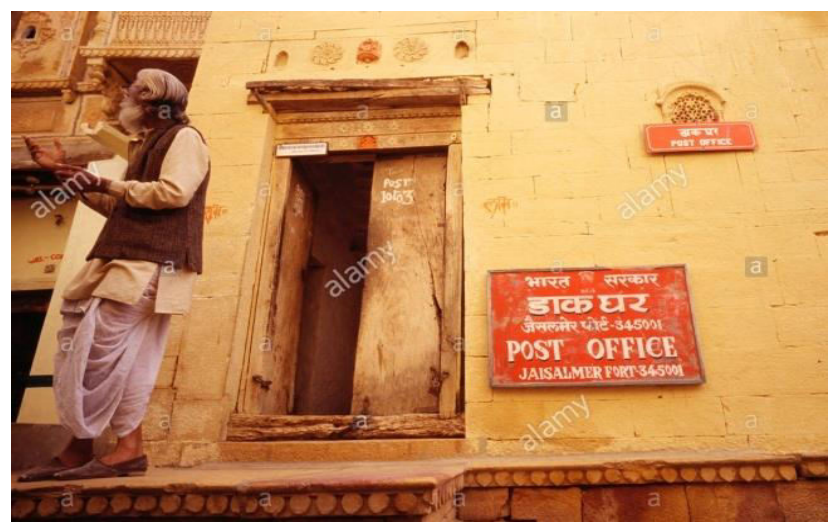

Fig 11: Jaisalmer (Rajasthan).

Jaisalmer, a border town, with high desert around the city. The city popular with the titles of Sun City or blue city, has many historic creatures attracting many travellers across the globe to come and stay for long. The post offices at the Jaisalmer Fort attract many comes the fort. The post office is specifically cultured in the tone of traditional Rajasthani Marwari town old house, truly giving a glaze of a living experience. Tourist comes here to especially post, purchase post cards, stamps and other philately at the post office. It adds on to the cultural heritage of the place in multifaceted ways (Fig 11 and Fig 12). cultural reference of the city. Coloured pink at most,

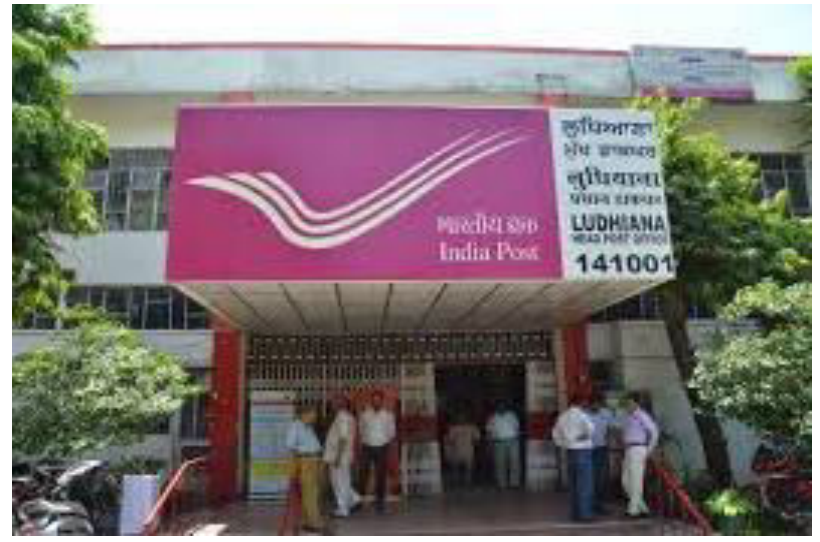

Fig 10: Ludhiana (Punjab).

on the Ferozepur Road, a key highway on the most urbane standings, the structure adds much to the cosmopolitan culture (Fig 9 and Fig 10).

Tourism in Rajasthan - Rajasthan (/'ra:dzəstæn/ Hindustani pronunciation: [ra:dzos' $\mathrm{t}^{\text {tha:n] }}$ is literally a "Land of Kings") (Boland-Crewe \& Lea, 2003) in northern India. (Ministry of Home Affairs; Ministry of Culture; Government of India) The state is a popular subject of tourism with its popular forts and desert.

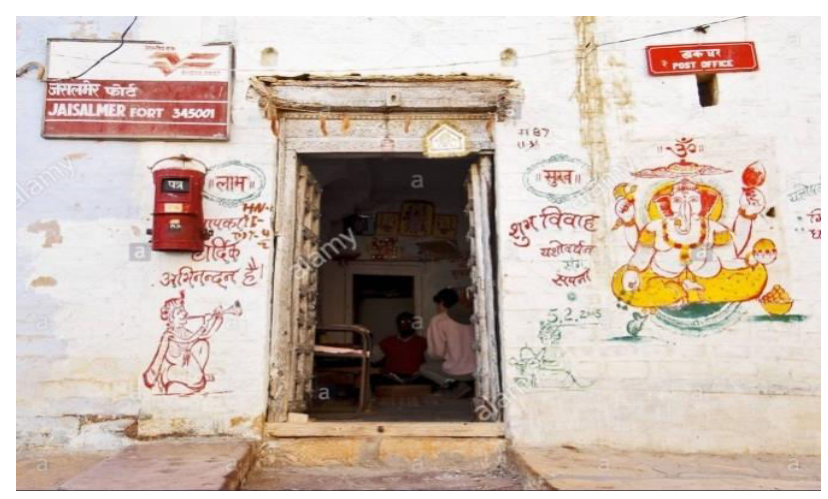

Fig 12: Jaisalmer Fort (Rajasthan).

Jaipur GPO, in the Pink City Jaipur, adds much to the the post office building seems to enriching the heritage image of the historic town at the centre of the metropolis. The places speak much about growth and development of the city from a dy-nasty to a metropolitan emerging as a leading one after NCT as a supplement to the growing needs. The first to be observed on any airport, first of its kind, Airport Sanganer Post Office at Jaipur Inter-national Airport, attracts many visitors, especially tourists to come at the place for their needs and cultural calls towards a post office and earn a new experience at the place (Fig 13 and Fig 14). 


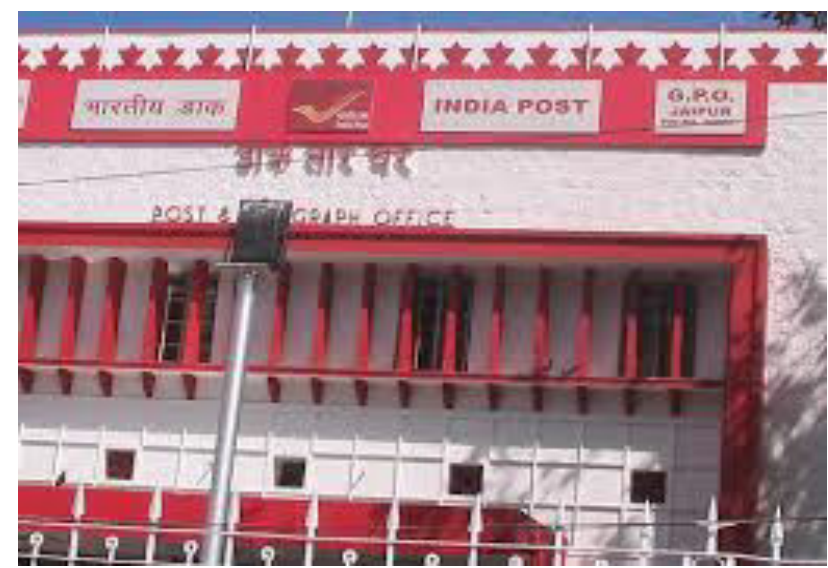

Fig 13: Jaipur (Rajasthan).
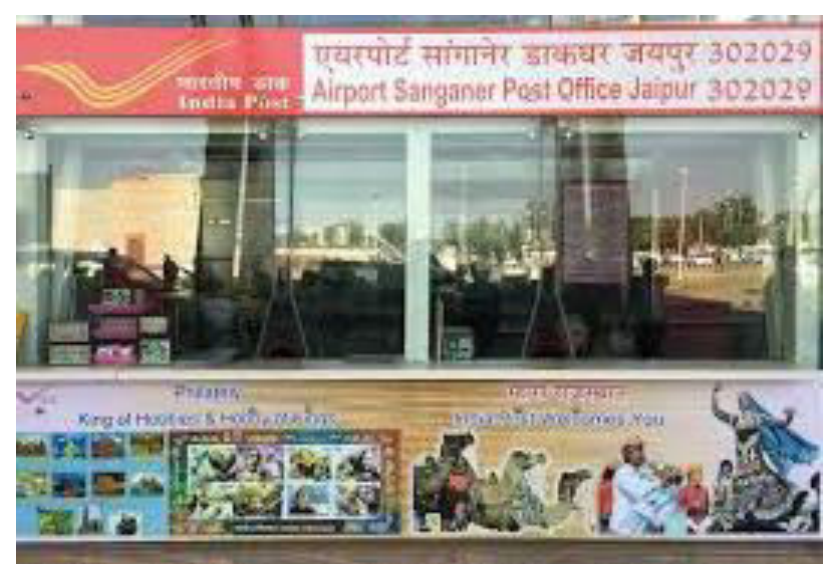

Fig 14: Sanganer Airport, Jaipur (Rajasthan).

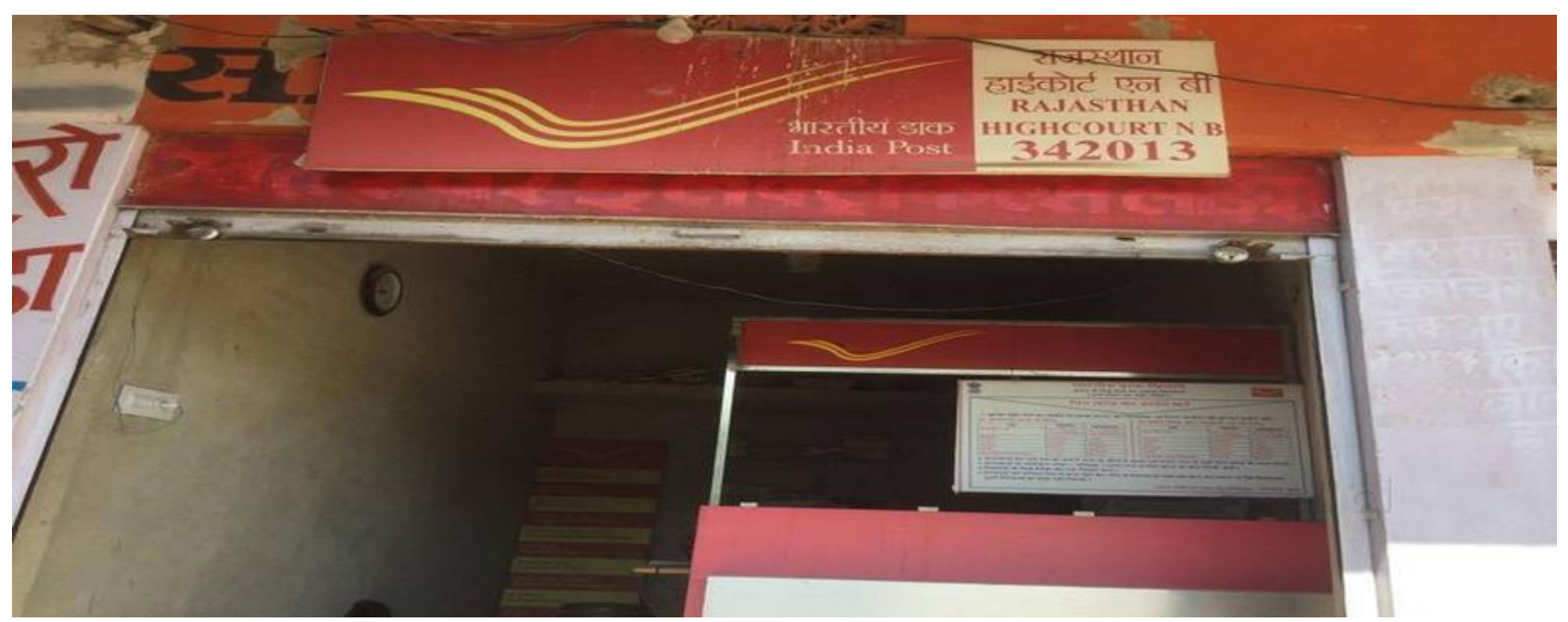

Fig 15: Jodhpur.

Jodhpur High Court in the historic town of Jodhpur have much cultural and tourism significance, as a popular public place. Attracting many to explore towards its ends. After the historical Lahore, Delhi, Mumbai and Chennai, this place has much to say about the Indian historical background of the subcontinent and speaks much about the modern city with its British era artefacts and architectures. The
Post Office adds its share to the cultural relevance and significance to place, and attracts many (Fig 15).

Jammu and Kashmir (UT) - Tourism has rebounded in recent years in the territory. The Hindu, (2009) People come here to see beautiful valleys and high snow mountains. They observe their hermitage at different shrines settled in the region.

\section{Role of India Post}

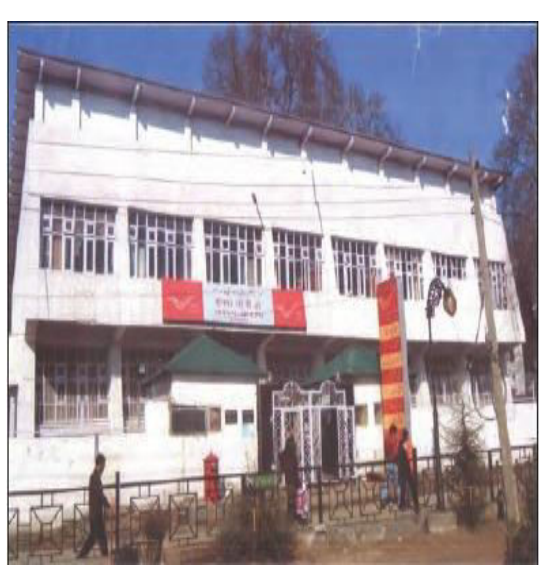

Fig 16: Srinagar (J\&K) GPO.

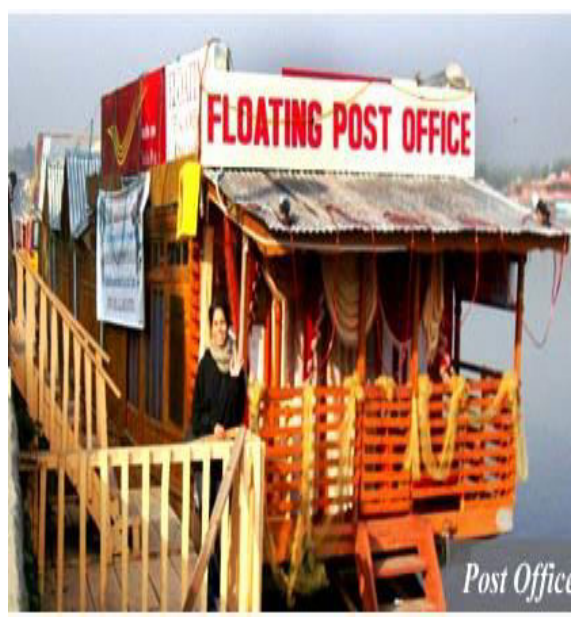

Fig 17: Dal Lake, Srinagar (J\&K).

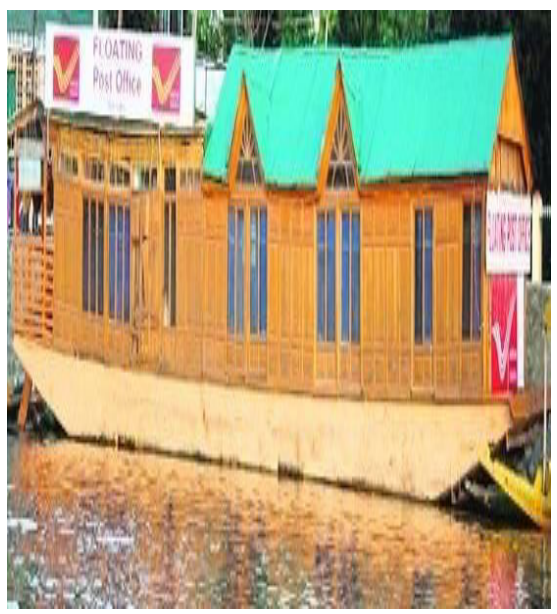

Fig 18: Dal Lake, Srinagar (J\&K). 
The Srinagar General Post Office in the Capital Town of the newly created Union Territory, has much to say of the cultural reference to kashmiriyat, housing many infamous lakes and monuments. Floating Post Office at the key attraction point of the city, unani- mously attracts the visitors to come towards and at least have one postal transact at the place. Many take the selfies with houseboat housing the office, as agreed towards memories (Fig 16, Fig 17 and Fig 18).

\section{Role of India Post in Ladakh (UT)}

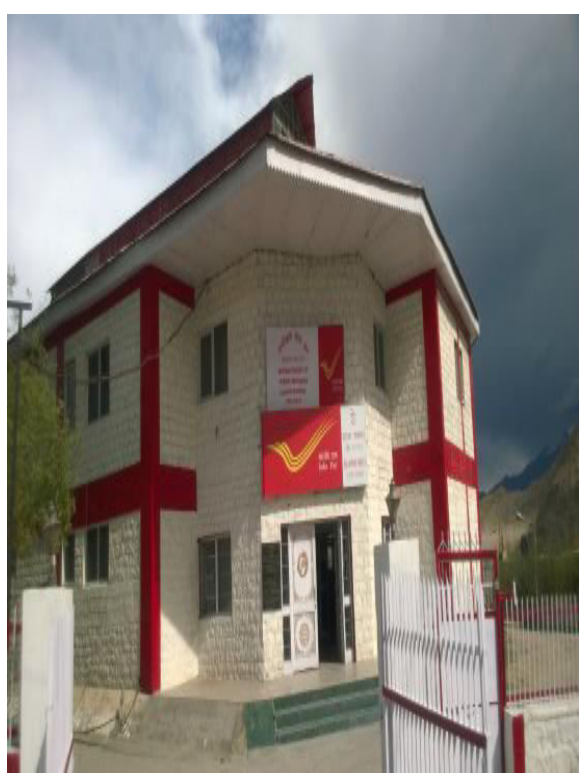

Fig 19: Leh HO (Capital).

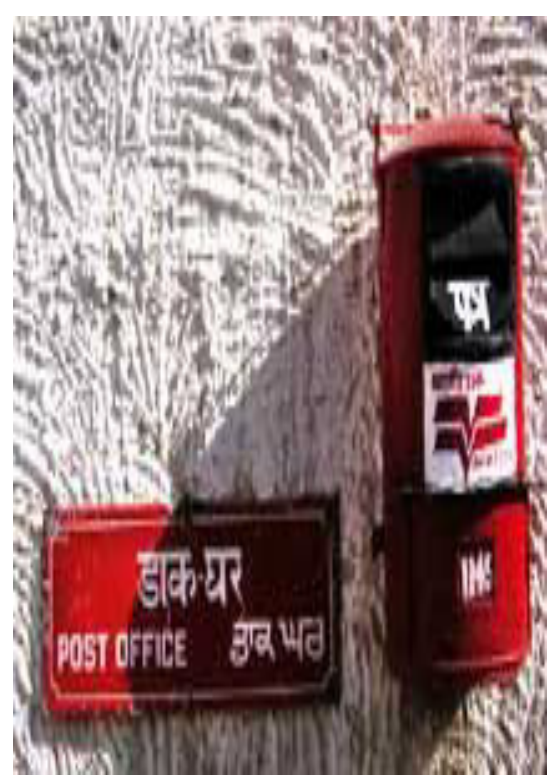

Fig 20: Ladakh HO.

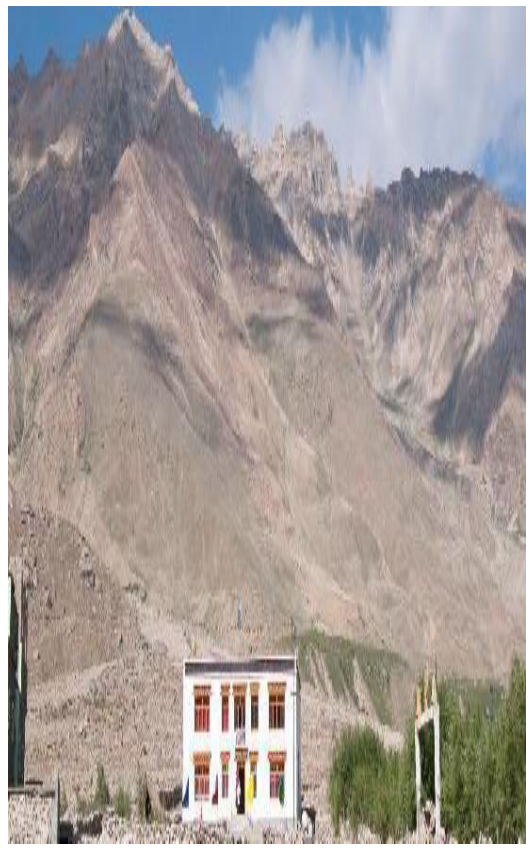

Fig 21: Kargil HO.
The post offices at Leh, Ladakh and Kargil have much cultural significance to tell its story. Leh is a scenic town and the capital town of the newly created UT, having a strengthened cultural and historic significance with many Buddhist monasteries and extremely diverse weather. The place gives a different and unique experience of stay, attracting many travellers across globe, from the ancient vedic era. The Head Post Office duly matches the cultural and topographic heritage, giving a blissful image of the historic town, hence adding to the tourism value. Ladakh is a 'Khushak' terrain with many of it monasteries and diverse landscapes attracting many bike lovers to the place at Ladakh regionalism attract many such bikers and explorers to give a visit to the place and transact at the post office. The post office at Kargil, a post and small town at LOC between India controlled and Pakistan occupied Indian region, has a different cultural relevance and experiential stories. Extremist travellers come, visit the place and the post office and hence experience a landmark telling the story of a place, mostly in diverse weather or security and strategy (Fig 19, Fig 20 and Fig 21).

Uttarakhand - Utarakhand (/, vtə'ra:kınd/) (Dictionary.com) is often attached with Gods. (The Daily
Pioneer, on 4 March 2020), Gairsain was declared the summer capital of the state, (News 18) also known as 'Kurmanchal Kingdom'. (Pande, 1993) Haridwar, Dehradun and Pauri Garhwal District and Uttarkashi District include some other protected areas in the state. (uttarakhandforest.org) Local crocodiles were saved from extinction. (Princeton University Press) A critically endangered bird, last seen in 1876 is the Himalayan quail endemic to the western Himalayas of the state. (corbett-nationalpark.com).

Role of India Post - Almora (Uttarakhand) is an small town and district headquarter of district Almora. Settled in cape of Ganges and Yamuna, the city has a scenic beauty. Almora HO, framed in the landscaped hilly beauty, gives an embellishing touch to the visitors, coming towards the place for their travelling exploration. Pithoragarh (Uttarakhand) is again settled in Garhwal region on the high Ganges and its tributaries. The Head Post Office gives a mesmerizing experience to the visitors. The post offices at Dehradun, Rishikesh and Haridwar further picturised it (Fig 22 and Fig 23). 


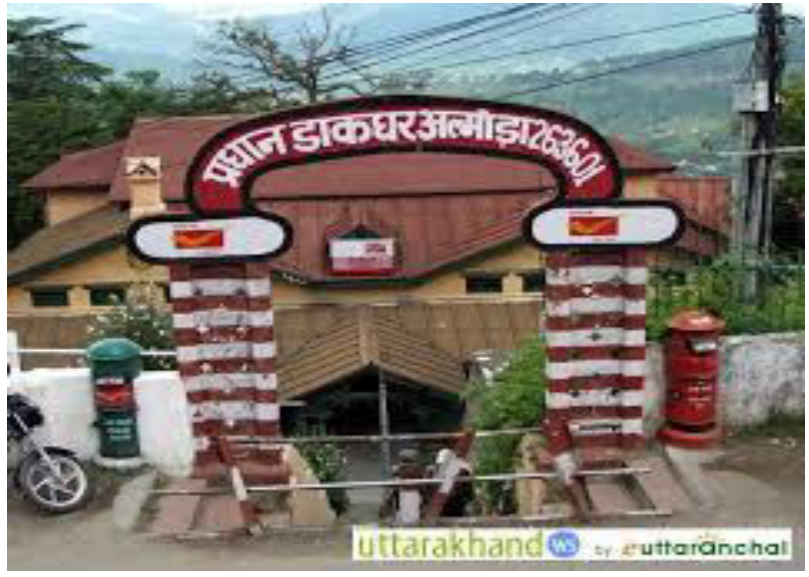

Fig 22: Almora (Uttarakhand).

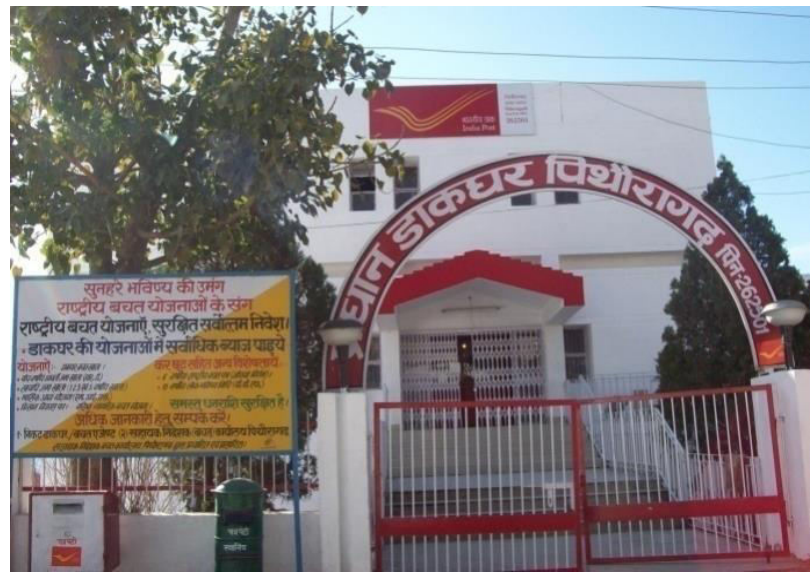

Fig 23: Pithoragarh (Uttarakhand).

\section{Role of India Post at Other Places}

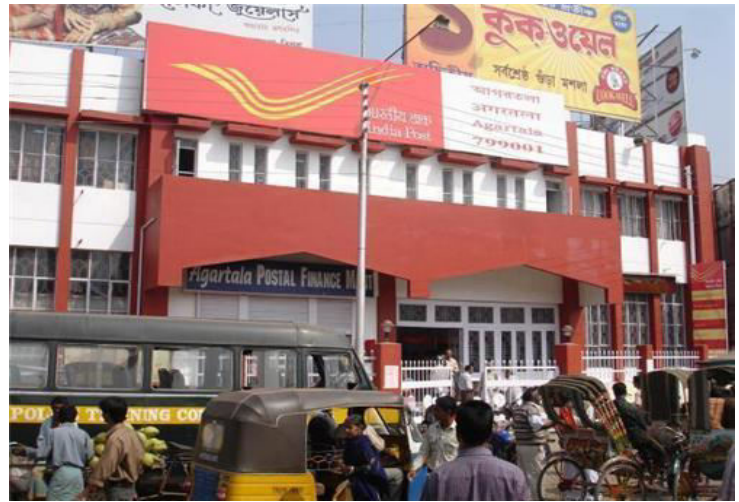

Fig 24: Agartala Post Office (Tripura).

Agartala Post Office gives a promising mark to the visitors and explorers to the cityscape, enriching the urbane of northeast capital town. Waltair Head Office in a small agriculturist and Pisciculture dependent town near Vishakhapatnam port gives a nice view to

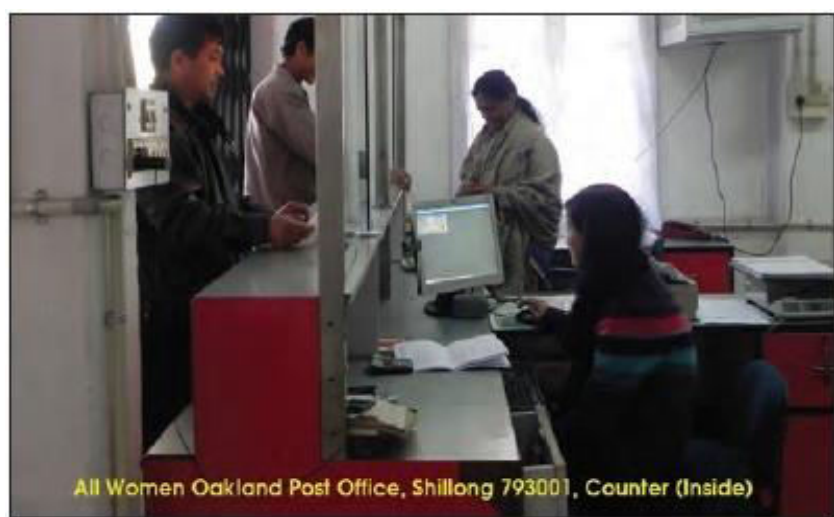

Fig 26: Oakland, Shillong (Meghalaya)

All Women Post Office at Oakland, Shillong (Meghalaya) settled in north-east is giving a new message and is bringing up a feminine revolution, along with all India women bank. The place unanimously attracts explorers and visitors to come up to explore the place as a new and unique initiative towards women UniversePG I www.universepg.com

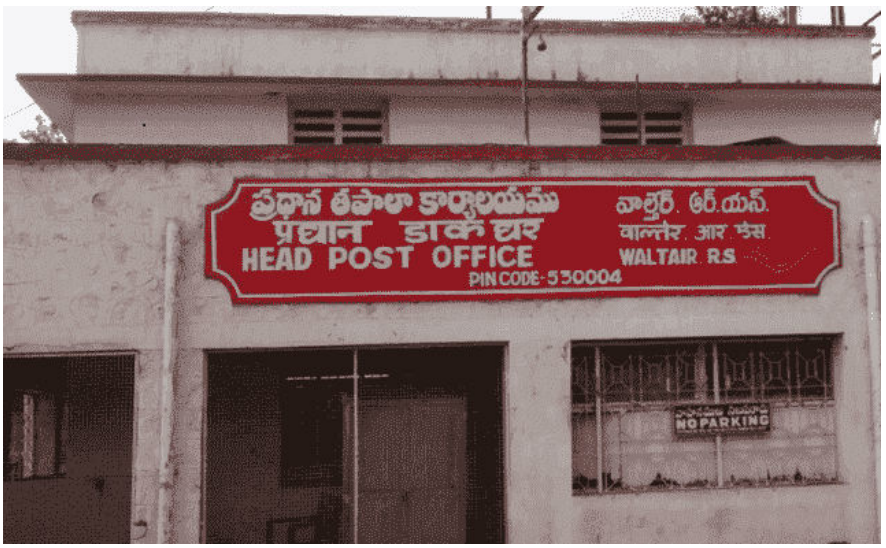

Fig 25: Waltair HPO, VIZAG, Vishakhapatnam (A.P.).

the visitors, visiting the cultural and commercial rural town setup in the Nilgiris region. The office reveres old cultural reverence in a rural locale of a south Indian setup (Fig 24 and Fig 25).

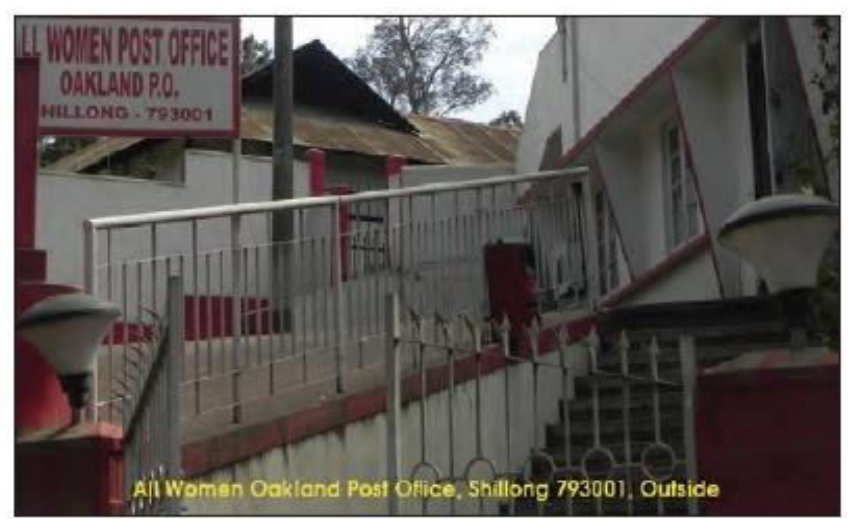

Fig 27: All Women Post Office.

empowerment. Yet, those settled in nilgiris, on blissening valley of utakmund or of mount abu, backwaters of waltair or kerala, enjoying and mush rooming the glory of regional tourism. We were able to cover only a few of them (Fig 26 and Fig 27). 


\section{CONCLUSION AND RECOMMENDATION:}

The paper studied tourism related perspectives of India post regarding the post offices located in the tourism hotspots in NW India. The study mainly discusses tourism in Delhi NCT, Himachal Pradesh, Punjab (India), Rajasthan, Jammu and Kashmir (union territory), Ladakh (union territory), and Uttarakhand among others, and Role of India Post in boosting the tourism aspects thereupon. There in as such. As acknowledged in the study, Postal Services network provide very important amenity at all the places. At many places, as indicated above, in helps in enhancing the tourism related prospects of locality and some time tourism at a place. It has an important place in Indian heritage, culture and tourism prospects. The research will be very useful for the stakeholders, keen to look tourism and utilize the additional opportunity from this perspective. Specially, it is beneficial for other prospective tourism related partners, to expand the business activities in sphere of postal tourism, by developing a fully fledged tourism circuit. India Post may conduct a full fledged research in this behalf. Future research may take the stakeholders perception on the aspect, focusing a primary data analysis.

\section{ACKNOWLEDGEMENT:}

We duly acknowledge all the persons and sources, who have directly or indirectly contributed to the preparation of this study and manuscripts. Our special thanks to the authorities and officials of Dept. of Posts, Government of India for its different circles. We also duly thank the authorities and officials of concerned departments and universities as a whole, which facilitated the compilation of this research work, using their valuable resources.

\section{CONFLICTS OF INTEREST:}

The author(s) have no conflict of interest regarding the publication of this manuscript.

\section{REFERENCES:}

1) Amritsar-based Partition Museum to ink pact with Manchester Museum, Hindustan Times, (2019). Available from -

https://www.hindustantimes.com/india-news/pa rtition-museum-to-ink-pact-with-manchester-m useum/story-Hxc1q5a2CJ6Pn3Ah1FNxVK.html

2) Asher, C. B. (2000). Chapter 9: Delhi walled: Changing Boundaries. In James D. Tracy (ed.).
City Walls. Cambridge University Press. pp. 247-281. Available from -

https://books.google.co.in/books?id=gSupaU3vV acC\&pg=PA249\&redir esc $=y \& h l=e n$

3) A Rare Visit of Ben Goose at Corbett. corbettnational-park.com., 11 May 2012.

htps://www.corbett-national-park.com/blog/arare-visit-of-ben-goose-at-corbett.htmlt

4) Bandi Chhor Divas Reflection, (2016). A Lesson in Selflessness. SikhNet. https://www.sikhnet.com/news/bandi-chhor-div as-reflection-lesson-selflessness

5) Census, (2011). Chapter 6 (State of Literacy), p.14 (PDF). Government of India. https://www.censusindia.gov.in/2011-provresu lts/data files/India/Final PPT 2011 chapter6.pd $\mathrm{f}$

6) Chapter 3: State Economy. Planning Department, Government of Delhi (p. 16). http://delhiplanning.nic.in/sites/default/files/3\%2 9\%20State\%20Economy.pdf

7) Chauhan, P. (2019). Bill to make Sanskrit second official language of HP passed. The Tribune. Shimla. Available from https://www.tribuneindia.com/news/archive/him achal/bill-to-make-sanskrit-second-official-lan guage-of-hp-passed-730075

8) Chopra, J. (2017). "Devbhumi Uttarakhand: The original land of yoga". The Daily Pioneer. https://www.dailypioneer.com/

9) Corruption on decline in India; Karnataka ranked most corrupt, Himachal Pradesh least: Survey. Zee News, (2017). Available from: https://zeenews.india.com/economy/corruptionon-decline-in-india-karnataka-ranked-most-cor rupt-himachal-pradesh-least-survey-2000205. $\underline{\mathrm{html}}$

10) Define Uttarakhand at Dictionary.com, (2013). https://www.dictionary.com/browse/uttarakhand

11) Foreign tourists flock Kashmir, (2009). Online edition of The Hindu. Chennai, India. 18 March. Available from -

https://www.thehindu.com/features/metroplus/tra vel/foreign-tourist-arrivals-up-by-53-in-a-y ear/article2450248.ece

12) Himachal Pradesh Profile Census of India, (2011). Available from -

https://censusindia.gov.in/2011census/censusinfo dashboard/stock/profiles/en/IND002 HimachalP radesh.pdf 
13) Himachal Pradesh Vidhan Sabha. Hpvidhansabha.nic.in., (2011). Available from https://hpvidhansabha.nic.in/

14) HP least corrupt state: CMS-India study. The Times of India, (2017). Available from https://timesofindia.indiatimes.com/city/shimla/h p-least-corrupt-state-cms-india-study/articlesh ow/58439057.cms

15) Hola Mohalla Facts, History, Rituals Surrounding the Sikh Festival, IB Times, (2015). https://www.ibtimes.com/hola-mohalla-2015-fa cts-history-rituals-surrounding-sikh-festival-ph otos-1838872

16) Hossain MA, Suchana JJ, and Avi MAR. (2020). Promoting Bangladesh tourism through the internet: theoretical perspectives and empirical evidence, Can. J. Bus. Inf. Stud., 2(5), 8795. https://doi.org/10.34104/cjbis.020.087095

17) IANS, (2019). Justice Lingappa Narayana Swamy Takes Oath as Himachal Chief Justice. NDTV.com. Available from https://www.ndtv.com/india-news/justice-ling appa-narayana-swamy-takes-oath-as-himachalchief-justice-2112635

18) India Post, (2020). Indian Post Office: Happy to help during lockdown. India Post News Weekly. New Delhi: Department of Posts, GOI. https://www.indiapost.com/indian-post-officehappy-to-help-during-lockdown/

19) Inter-State Council Secretariat - Ministry of Home Affairs, Government of India. Ministry of Home Affairs, (2017). Available from https://www.mha.gov.in/division of mha/centre -state-division/inter-state-council-secretariat

20) Jama Masjid, India's largest mosque. Terragalleria.com. Available from https://www.terragalleria.com/asia/india/delhi/pi cture.indi38660.html

21) Know India.knowindia.gov.in. Available from https://knowindia.gov.in/

22) Kullu Dussehra, Kullu. Himachal Tourism. https://himachaltourism.gov.in/fairs-fests/

23) Maghi Mela: Four political parties erect stages to hold conferences. Indian Express. https://indianexpress.com/article/cities/chandigar h/manpreet-badal-to-seek-support-at-maghimela/

24) MOSPI Gross State Domestic Product. Ministry of Statistics and Programme Implementation, Government of India, (2019), National Philatelic Museum, Delhi Tourism. http://mospi.nic.in/133-gross-domestic-product

25) NDTV Food, (2016), Himachal Pradesh Food: 10 Best Recipes. NDTV. Available from https://food.ndtv.com/lists/himachal-pradeshfood-10-best-recipes-1442434

26) North Zone Cultural Centre. www.culturenorthindia.com. Ministry of Culture, Government of India.

27) Post Offices making special efforts to serve far-flung areas of J-K, Ladakh. ANI. https://www.aninews.in/news/national/generalnews/post-offices-making-special-efforts-to-ser ve-far-flung-areas-of-j-k-ladakh20200415213 405/

28) Prehistory and Protohistory, Official Website of Panchayati Raj Department, Government of Himachal Pradesh. Available from https://hppanchayat.nic.in/

29) Punjab Profile(PDF). censusindia.gov.in. https://www.censusindia.gov.in/2011census/cens usinfodashboard/stock/profiles/en/IND003_Punj ab.pdf

30) Punjab, Overseas Indian Facilitation Centre. https://www.mea.gov.in/overseas-indian-centresabroad.htm

31) Report of the $50^{\text {th }}$ Commissioner for linguistic minorities, Commissioner for Linguistic Minorities, Ministry of Minority Affairs, Government of India. Report of the Commissioner for Linguistic Minorities in India, (July 2012 to June 2013). Available from -

http://14.139.60.153/bitstream/123456789/10182 11/50th.pdf

32) Report of the Commissioner for linguistic minorities: $52^{\text {nd }}$ report Commissioner for Linguistic Minorities, Ministry of Minority Affairs, Government of India, (2014-2015) pp. 33-34. Available from https://minorityaffairs.gov.in/sites/default/files/2. \%2052nd\%20Report\%20English.pdf

33) Sikhs celebrate Diwali and Bandi Chhor Divas at Ilford gurdwara. Ilford Recorder. https://www.ilfordrecorder.co.uk/news/sikhs-ce lebrate-diwali-and-bandi-chhor-divas-at-ilfordgurdwara-3005450

34) State Wise Data. esopb.gov.in. Economic and Statistical Organization, Government of Punjab. Available from - https://esopb.gov.in/

35) Statistical Facts about India. indianmirror.com. https://www.indianmirror.com/geography/geo9.h $\underline{\mathrm{tml}}$ 
36) Sub-national HDI - Area Database. Global Data Lab. Institute for Management Research, Radboud University. Available from: https://globaldatalab.org/shdi/shdi/

37) The Bhangra Breakdown - June 2014 Ed. The Times of India, June 2014. Available fromhttps://timesofindia.indiatimes.com/defaultinterst itial.cms

38) The Globalisation of Bhangra Music. The Times of India. Available from https://timesofindia.indiatimes.com/defaultinterst itial.cms

39) "This study settles the Delhi versus Mumbai debate: The Capital's economy is streets ahead". Scroll.in. Available from https://scroll.in/article/896594/this-study-settlesthe-delhi-versus-mumbai-debate-the-capitalseconomy-is-streets-ahead

40) "Thousands converge in Punjab for Hola Mohalla". The Times of India. March 6, 2015. https://www.indiatoday.in/india/story/holamohalla-punjab-holi-anandpur-sahib-goldentemple-243193-2015-03-06

41) "Wildlife Eco-Tourism in Uttarakhand" (PDF). uttarakhandforest.org. Available from https://uttarakhandforest.org/

42) Sudarshan Chakra had made 51 pieces of Goddess Sati, part of the body was cut here too, Dainik Bhaskar. (2015). Available from https://epaper.bhaskar.com/

43) Pande, B. (1993). History of Kumaun : English version of "Kumaun ka itihas". Shree Almora Book Depot. Available from https://books.google.co.in/books/about/History of_Kumaun.html?id=BXZwQgAACAAJ\&redir esc $=\mathrm{y}$

44) Reddy, R. R. (2019). Telangana's 'people's leader' Bandaru Dattatreya appointed Himachal Pradesh Governor. The Hindu.
45) Riley, L. \& Riley, W. (2005). Nature's Strongholds: The World's Great Wildlife Reserves. p. 208. Princeton University Press.

46) Roach, P. (2011). Cambridge English Pronouncing Dictionary. $18^{\text {th }}$ ed. Cambridge: Cambridge University Press.

47) Sardar S, Hossain ME, Hossain MI, and Islam MS. (2020). Factors affecting visitor's satisfaction: an empirical study on the Paharpur Buddha Vihara, Naogaon, Rajshahi, Int. J. Manag. Account. 2(4), 61- 73. https://doi.org/10.34104/ijma.020.061073

48) Sharma, A. (2016). "Himachal becomes India's second 'Open Defecation Free' state, to get Rs 9,000 cr funding from World Bank". The Indian Express. Shimla. Available from https://indianexpress.com/article/india/india-ne ws-india/himachal-pradesh-open-defecation-fr ee-state-world-bank-funding-3727500/

49) Singh, M. (1988). History and Culture of Panjab. Atlantic Publishers \& Distributors.

50) Swamy, M. R. N. (2006). New Delhi. Marshall Cavendish. pp. 14-17. Available from https://books.google.com.au/books?id=VCX1Ur CinO4C

51) Trivedi, A. (2020). Gairsain to be U'khand's Summer Capital, Says CM Trivendra Rawat in Assembly; Meets Long-sought Demand. News 18. Available from -

https://www.news18.com/news/politics/gairsainto-be-uttarakhands-summer-capital-says-cmtrivendra-rawat-in-state-assembly-2525703.html

52) United Nations, (2016). the World's Cities in 2016 (PDF). United Nations - iLibrary. September 2016, p. 4. Available from https://doi.org/10.18356/8519891f-en

53) Wells, J. C. (2008). Longman Pronunciation Dictionary. $3^{\text {rd }}$ ed. Longman. India, Can. J. Bus. Inf. Stud., 3(4), 60-69. https://doi.org/10.34104/cjbis.021.060069 @ @ 